Proceedings of the 3rd International Congress APMAS2013, April 24-28, 2013, Antalya, Turkey

\title{
Wear Properties of Gabbro Based Glass and Glass-Ceramic Materials
}

\author{
G. BAYRAK* \\ Sakarya University, Arifiye Vocational High School, Department of Welding Technology \\ Esentepe Campus, 54187 Sakarya, Turkey
}

\begin{abstract}
Glass-ceramic materials were developed from gabbro including $\mathrm{MgO}$ and $\mathrm{Al}_{2} \mathrm{O}_{3}$ additives. Heat treatments for phase transformation from glassy matrix to glass-ceramic were carried out at $1000{ }^{\circ} \mathrm{C}$ for $3 \mathrm{~h}$. X-ray diffraction studies conducted on the glass-ceramic samples revealed that the phases formed in the glass-ceramics were cordierite, anorthite, diopsitic augite, forsterite and andesine. Glass and glass-ceramic materials were tested for wear properties against a harder alumina counterface using by a ball-on-disc tribometer at dry sliding condition. Wear tests were realized under the loads of $2.5,5$, and $7.5 \mathrm{~N}$ and at the sliding speeds of $0.1,0.2$, and $0.3 \mathrm{~m} / \mathrm{s}$. Wear rate of the glass and glass-ceramics ranged from $7.324 \times 10^{-7}$ and $2.150 \times 10^{-3}-9.971 \times 10^{-7}$ and $4.982 \times 10^{-5} \mathrm{~mm}^{3} / \mathrm{m}$, respectively. It was shown that the crystallization treatment caused the decrease of wear rate.
\end{abstract}

DOI: $10.12693 /$ APhysPolA.125.615

PACS: 46.55.+d, 64.70.P-, 61.43.Fs, 61.05.cp

\section{Introduction}

Gabbro which is a volcanic rock contains $\mathrm{SiO}_{2}$ between 45 and $52 \%$ values. In general, gabbro has dark gray or black color and with a solid structure. Gabbro is also called coarse-grained basalt. Glass-ceramics are polycrystalline solids prepared by the controlled crystallization of glasses. Controlled crystallization usually involves a two-stage heat treatment process, namely a nucleation stage and a crystallization stage. Augite, diopside, anorthite, andesine, and cordierite are common phases in the glass-ceramic materials [1-4]. As an important engineering material family, the glass-ceramic materials may find use in many areas such as vacuum, sealing, electronics, biomedical materials, kitchen ware, and defense industries and especially orthopedic and dental implants [5-7]. Glass-ceramic materials can be obtained from having suitable composition of volcanic rock (such as basalts) by controlled crystallization heat treatment process $[2-4]$.
Moreover, there can be also obtained industrial wastes. At the beginnings of this wastes which is blast furnace slag, there is contained high amount of $\mathrm{CaO}, \mathrm{SiO}_{2}$, and $\mathrm{MgO}$ and small amount of $\mathrm{MnO}$ and $\mathrm{Fe}_{2} \mathrm{O}_{3}$, and it is possible that to produce glass-ceramic from a waste of thermal power plants flying ashes $[8,9]$.

The aim of the study was to investigate the wear behavior of glass-ceramic materials from natural rock gabbro including $\mathrm{MgO}$ and $\mathrm{Al}_{2} \mathrm{O}_{3}$ additives.

\section{Experimental procedure}

10.8 wt $\% \mathrm{MgO}$ and 7.48 wt $\% \mathrm{Al}_{2} \mathrm{O}_{3}$ were added to gabbro obtaining increase in mechanical properties and sieved to the grids of $-100 \mu \mathrm{m}$. The glass batch mixture were melted in $\mathrm{Al}_{2} \mathrm{O}_{3}$ crucible at $1500^{\circ} \mathrm{C}$, then cast into a graphite mold and annealed at $600^{\circ} \mathrm{C}$. The composition of gabbro rock and the calculated chemical composition of the glass melt were shown in Table (LOI $=$ loss on ignition).

TABLE I

Chemical analysis of the gabbro rock and the calculated chemical composition of the glass (in wt\%).

\begin{tabular}{l|c|c|c|c|c|c|c|c|c|c|c}
\hline \hline & $\mathrm{SiO}_{2}$ & $\mathrm{Al}_{2} \mathrm{O}_{3}$ & $\mathrm{MgO}$ & $\mathrm{CaO}$ & $\mathrm{Na}_{2} \mathrm{O}$ & $\mathrm{K}_{2} \mathrm{O}$ & $\mathrm{Fe}_{2} \mathrm{O}_{3}$ & $\mathrm{TiO}_{2}$ & $\mathrm{P}_{2} \mathrm{O}_{5}$ & $\mathrm{MnO}$ & $\mathrm{LOI}$ \\
\hline gabbro & 51.35 & 14.13 & 4.7 & 7.78 & 3.63 & 1.15 & 13.63 & 1.96 & 0.28 & 0.17 & 0.94 \\
\hline glass & 41.95 & 19.03 & 14.66 & 6.36 & 2.97 & 0.94 & 11.14 & 1.60 & 0.23 & 0.14 & 0.77
\end{tabular}

After casting process, it was seen that gabbro based samples were determined as amorphous state confirmed by X-ray diffraction (XRD) analysis. Gabbro based glass

\footnotetext{
*e-mail: gunhanb@sakarya.edu.tr
}

were crystallized for glass-ceramic transformation from glassy amorphous state at $1000^{\circ} \mathrm{C}$ for $3 \mathrm{~h}$ to promote internal crystallization. The crystalline phases in glass-ceramics were characterized by XRD analysis (Rigaku D/Max). Ball-on-disk arrangement was used for friction and wear test. The $\mathrm{Al}_{2} \mathrm{O}_{3}$ ball, $10 \mathrm{~mm}$ in diameter, was used in the wear test. Most of the materials are encountered with ambient temperature and humidity in the in- 
dustrial applications. Therefore, the friction and wear tests were carried out at room temperature $\left(21 \pm 3{ }^{\circ} \mathrm{C}\right)$, relative humidity being $64 \pm 5$ conditions. Wear tests were carried out under the loads of $2.5,5$, and $7.5 \mathrm{~N}$ at $0.1,0.2$, and $0.3 \mathrm{~m} / \mathrm{s}$ sliding speeds. Optical microscope (Olympus BHM $313 \mathrm{U}$ ) was used to study the wear microstructure.

\section{Results and discussion}

XRD analyses of gabbro based glass and glass-ceramics were given in Figs. 1 and 2 . As seen in Fig. 1 gabbro based sample was glassy amorphous structure. The phases identified in gabbro based glass-ceramics subjected to heat treatment at $1000^{\circ} \mathrm{C}$ for $3 \mathrm{~h}$ (Fig. 2) are cordierite $\left[(\mathrm{Mg}, \mathrm{Fe})_{2} \mathrm{Al}_{4} \mathrm{Si}_{5} \mathrm{O}_{18}\right]$, anorthite $\quad\left[\mathrm{Na}_{0.05} \mathrm{Ca}_{0.95} \mathrm{Al}_{1.95} \mathrm{Si}_{2.05} \mathrm{O}_{8}\right], \quad$ augite $\left[(\mathrm{Ca}, \mathrm{Na})(\mathrm{Mg}, \mathrm{Fe}, \mathrm{Al}, \mathrm{Ti})(\mathrm{Si}, \mathrm{Al})_{2} \mathrm{O}_{6}\right], \quad$ andesine $\left[(\mathrm{Ca}, \mathrm{Na})(\mathrm{Al}, \mathrm{Si})_{4} \mathrm{O}_{8}\right]$, diopside $\left[\mathrm{CaMg}\left(\mathrm{Si}_{2} \mathrm{O}_{6}\right)\right]$ and forsterite $\left[(\mathrm{Mg}, \mathrm{Fe})_{2} \mathrm{SiO}_{4}\right]$. These crystalline phases are the most common phases in the glass-ceramic materials produced from natural rock [1-4].

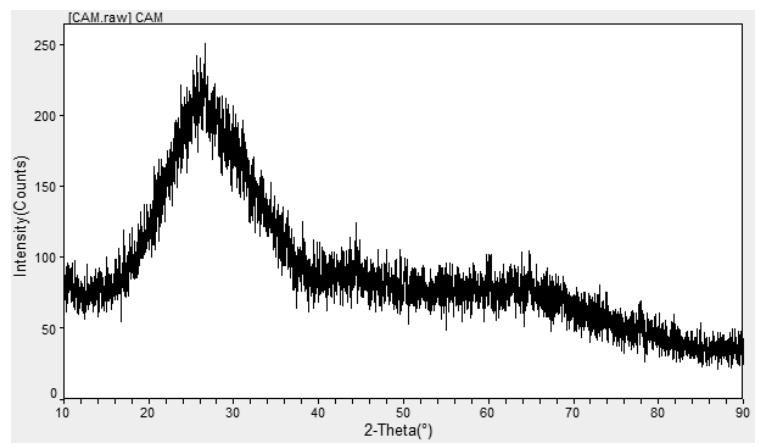

Fig. 1. XRD pattern of the gabbro based cast sample.

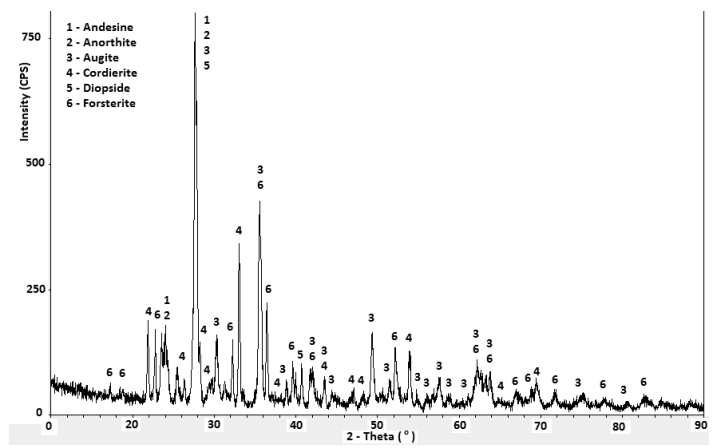

Fig. 2. XRD pattern of the gabbro based glass-ceramic controlled crystallized at $1000^{\circ} \mathrm{C}$ for $3 \mathrm{~h}$.

Micrographs of worn surface of gabbro based glass and glass-ceramic were given in Fig. 3. As seen in the micrographs, wear track of gabbro based glass-ceramic was narrower than gabbro based glass. It was clearly understood that gabbro based glass-ceramic was less eroded than gabbro based glass clearly.

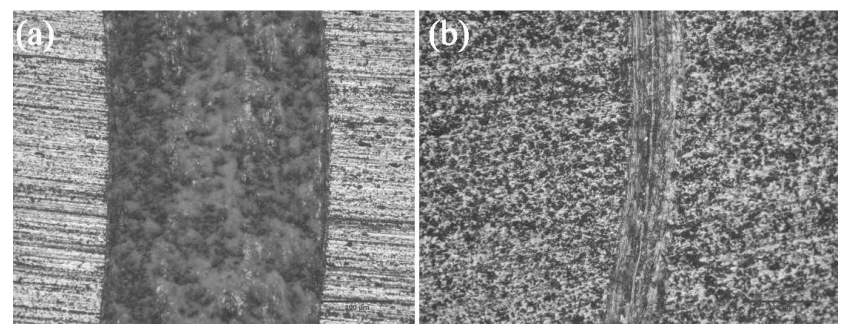

Fig. 3. Micrographs of the worn surface at the $0.2 \mathrm{~m} / \mathrm{s}$ wear rate and $5 \mathrm{~N}$ load. (a) Gabbro based glass, (b) gabbro based glass-ceramic.

As shown from Fig. 3, the wear track formed on the gabbro based glass is much wider than that of the track formed on the glass-ceramic. Archard explained that the hardness of the materials is an effective property to withstand against the materials couple working each other. The wear track of the gabbro base glass exhibits abrasive wear with the debris formed on the track and grounded abrasively. Track formed on the glass-ceramic includes some tiny groves. The wear mechanism is mild and moderate abrasive wear [10].

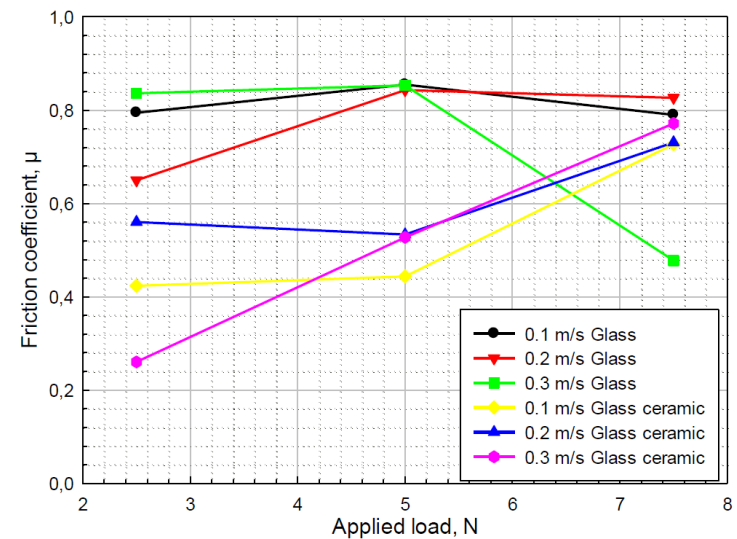

Fig. 4. The variation of friction coefficients as a function of applied load for glass and glass-ceramic.

Figure 4 shows the variation of friction coefficients as a function of applied load for glass and glass-ceramic. It is clear from this figure that the effect of the applied load on the friction coefficient caused the increase of friction coefficient, slightly for glass and glass-ceramic. As shown from the figure, the friction coefficient of the glass is much higher than that of the glass-ceramic. Increase in applied load caused the closing up of the friction coefficient of the glass and glass-ceramics. Sliding speeds do not have any important effect on the friction coefficient. Only glass material tested of $0.3 \mathrm{~m} / \mathrm{s}$ sliding speed and $7.5 \mathrm{~N}$ applied load showed a decrease on the friction coefficient because of the produced worn debris much more.

The variation of wear rate as a function of applied load for glass and glass-ceramic was given in Fig. 5. It is clear from this figure that the effect of increasing applied load 


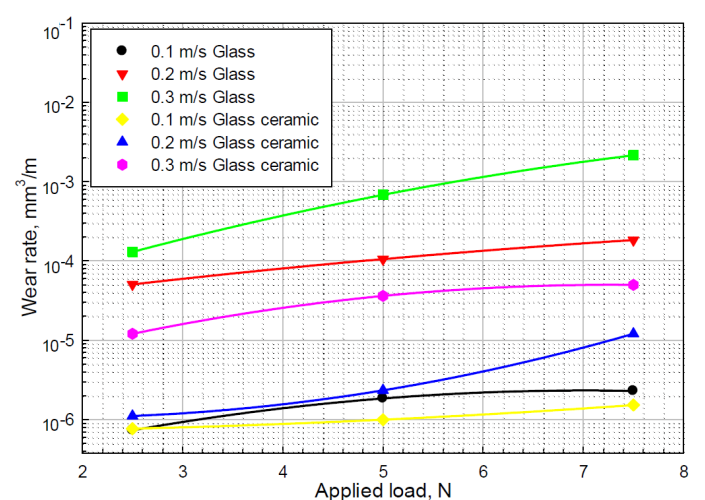

Fig. 5. The variation of wear rate as a function of applied load for glass and glass-ceramic.

and sliding speeds for all tested materials caused the increase of the wear rate. In addition this, the wear rate was decreased with glass-ceramic transformation. Figure 5 shows that the wear rate of glass-ceramic is lower than that of the gabbro based glass. Wear rate of the glass and glass-ceramics ranged from $7.324 \times 10^{-7}$ and $2.150 \times 10^{-3}-9.971 \times 10^{-7}$ and $4.982 \times 10^{-5} \mathrm{~mm}^{3} / \mathrm{m}$, respectively.

\section{Conclusions}

In the present study, the wear behavior of glass and glass-ceramic produced from gabbro was investigated. Cordierite, anorthite, diopsidic augite, forsterite, and andesine phases were detected in the gabbro based glass ceramics by XRD analysis. The friction coefficient of the gabbro based glass is much higher than that of the glass-ceramic produced from gabbro. The friction coefficient of the glass and glass-ceramics ranged from 0.48 to 0.85 and 0.26 to 0.77 , respectively. The effect of the applied load on the friction coefficient caused the increase of friction coefficient for glass and glass-ceramic, slightly. The friction coefficient of the glass is much higher than that of the glass-ceramic. Increase in applied load caused the closing up of the friction coefficient of the glass and glass-ceramics.

The effect of increasing applied load and sliding speeds for all tested materials caused the increase of the wear rate. In addition to this, the wear rate was decreased with glass-ceramic transformation. The wear rate of glass-ceramic is lower than that of the gabbro based glass. Wear rate of the glass and glass-ceramics ranged from $7.324 \times 10^{-7}$ and $2.150 \times 10^{-3}-9.971 \times 10^{-7}$ and $4.982 \times 10^{-5} \mathrm{~mm}^{3} / \mathrm{m}$, respectively.

The wear track of the gabbro based glass exhibits abrasive wear with the debris formed on the track and grounded abrasively. Whereas, track formed on the glass-ceramic includes some tiny groves. The wear mechanism is mild and moderate abrasive wear.

\section{References}

[1] G.W. Tyrell, The Principles of Petrology, Wiley, New York 1975.

[2] P.W. McMillan, Glass-Ceramics, 2nd ed., Academic Press, London 1979.

[3] S. Yilmaz, Ph.D. Thesis, Istanbul Technical University, 1997.

[4] S. Yilmaz, G. Bayrak, S. Sen, U. Sen, Mater. Des. 27, 1092 (2006).

[5] G. Madhumita, P. Sengupta, S. Kuldeep, R. Kumar, V.K. Shrikhande, J.M.F. Ferreira, G.P. Kothiyal, Ceram. Int. 33, 863 (2007).

[6] M. Amitava, J. Sunirmal, Bull. Mater. Sci. 24, 69 (2001).

[7] F.H. Elbatal, M.A. Azooz, Y.M. Hamdy, Ceram. Int. 35, 1211 (2009).

[8] M. Erol, S. Kucukbayrak, A.E. Mericboyu, M.L. Ovecoglu, J. Europ. Ceram. Soc. 21 , 2835 (2001).

[9] R.D. Rawlings, J.P. Wu, A.R. Boccaccini, J. Mater. Sci. 41, 733 (2006).

[10] V.K. Rai, R. Srivastava, S.K. Nath, S. Ray, Wear 231, 265 (1999). 